\title{
Urine and Milk of Dairy Animals as an Indicator of Hydrofluorosis
}

\author{
Shikha Raina,* Kirti Dua, Sikhtejinder Singh and Sushma Chhabra \\ Department of Veterinary Medicine, Guru Angad Dev Veterinary and Animal Sciences University, Ludhiana, INDIA \\ "Corresponding author: S Raina; E-mail: shikharaina2009@gmail.com
}

Received: 15 Oct., 2019 Revised: 21 Dec., $2019 \quad$ Accepted: 26 Jan., 2020

\begin{abstract}
The South-Western region of Punjab is endemic for hydrofluorosis and the livestock consuming fluoride rich water exhibit dental mottling and skeletal fluorosis. The present study was conducted in fluoritic areas of Mansa district of Punjab with an aim to find out the concentration of fluoride in urine and milk of dairy animals in relation to varying levels of fluoride concentration in drinking water of fluorotic areas and non fluoritic areas. For this, eight urine samples and six milk samples were collected from livestock consuming water having fluoride concentration upto $8 \mathrm{ppm}$. Urinary and milk F level was significantly high in dairy animals from the fluorotic area, ranging from 10 to $30 \mathrm{mg} / 1$ and 0.4 to $0.8 \mathrm{mg} / 1$ respectively as compared to animals from non fluorotic area that varied from $3-4 \mathrm{mg} / \mathrm{l} \mathrm{F}$ in urine and 0.04 to $0.08 \mathrm{mg} / \mathrm{l} \mathrm{F}$ in milk.
\end{abstract}

Keywords: Fluoride, urine, milk, hydrofluorosis

Fluoride is $13^{\text {th }}$ prevalent naturally occurring element in earth's crust. Since it is most electronegative of all chemical elements, it rarely exists in elemental form. As the ground water passes through the fluoride rich rocks, it carries fluoride with it, hence most of the fluoride is found in ground water than surface water. Fluoride contaminated areas are mostly characterized by the presence of crystalline basement rocks and/or volcanic bedrocks, arid, semi-arid climatic conditions and sedimentary aquifers undergoing ion exchange. Dissolution and weathering of $\mathrm{F}$ bearing minerals, pulled by calcite precipitation, is considered to be the dominant mechanism responsible for groundwater $\mathrm{F}$ contamination. Apart from these, anthropogenic source of $\mathrm{F}$ include phosphate fertilizers, animal and urban waste also contribute $\mathrm{F}$ in water.

In India, fluorosis is essentially hydrofluorosis and is endemic in parts of Punjab, Haryana, Rajasthan, Bihar, Madhya Pradesh, Orissa and Andhra Pradesh having high F levels in underground water, soils and forages (Randhawa and Singh, 2010). Water F concentration above $1.5 \mathrm{ppm}$, have been reported to cause osteo and dental fluorosis in a wide range of domestic animals (Modasiya, 2014). The livestock usually get exposed to fluorosis by excessive
Fluoride intake from mineral supplements, contaminated forages by certain industrial processes, drinking water, feed concentrates resulting in deposition of Fluoride in skeletal tissues and produce osteo-fluorotic lesions characterized by overt dental and bone lesions, lameness, deformed hooves, anemia, loss of body condition and emaciation. The bone lesions are associated with excessive mobilization of Calcium (Ca) and Phosphorous (P) to compensate for their increased urinary excretion in conjunction with fluorine (Radostits et al., 2007). The basic bed rocks of central India are contaminated with fluorite minerals and the overuse of groundwater for irrigation caused increased mineralization of $F$ in the groundwater and the excess $\mathrm{F}$ is excreted through urine of animals (Dahariya et al., 2015). Diagnosis of fluorosis can be done by screening feed and water samples given to the animals showing clinical signs of fluorosis and collection of blood, urine and milk samples from affected animals An increase in $\mathrm{F}$ concentration in drinking water there was an increase in concentration of $\mathrm{F}$ in cow's and buffalo's milk (Gupta et al., 2015; Pradhan et al., 2016).

How to cite this article: Raina, S., Dua, K., Singh, S. and Chhabra, S. (2020). Urine and milk of dairy animals as an indicator of hydrofluorosis J. Anim. Res., 10(1): 91-93. 


\section{MATERIALS AND METHODS}

The present study was conducted in Mansa district of Southwestern region of Punjab. The drinking water provided to the cattle, milk samples and urine samples were collected and examined for fluoride level. The research work was carried out in the Department of Veterinary Medicine, Guru Angad Dev Veterinary and Animal Sciences University, (GADVASU) Ludhiana, Punjab.

$\square$ Approximately $200 \mathrm{ml}$ of drinking water meant for livestock was collected in the acid washed plastic bottles and stored at room temperature till further analysis. Similarly, fresh Milk and urine samples were also collected from dairy animals in clean dry, tightly closed plastic bottles.

$\square \quad$ Samples were put in cooled icebox during transportation and stored at $10^{\circ} \mathrm{C}$ temperature in deep freeze for further analysis.

Estimation of Fluoride concentration in drinking water, milk and urine was done by using digital ion analyser (Orion 4 star bench top pH ISE meter, Thermo Scientific, Singapore) along with $\mathrm{F}$ selective electrode (Thermo Scientific, USA).

\section{Statistical Analysis}

The data was analysed by using SPSS (Statistical Package for Social Sciences) for Window version $16.0^{\circ}$ SPSS Inc. USA computer software program. The mean values of various parameters were calculated and presented along with respective standard errors and ranges.

\section{RESULTS AND DISCUSSION}

On the basis of survey, it was found that the animals consuming water having high fluoride content have subsequently high fluoride in urine as well as in the milk as compared to the animals from non fluoritic area.

\section{Fluoride (F) level in drinking water of livestock}

The mean concentration of $\mathrm{F}$ in the drinking water for dairy animals was found to be $3.71 \pm 1.01$, with values ranging from 2- $8 \mathrm{ppm}$ from Mansa district of Punjab. The critical limit of $\mathrm{F}$ in drinking water is $1.5 \mathrm{ppm}$ for livestock. Similar observations of hydroflurosis was reported by Singh (2012) in drinking water of Mansa, Bhikhi, Budhlada, Jhunir and Sardulgarh blocks in Mansa district. Similarly, Sharma et al. (2014) revealed high F level in drinking water of Faridkot and Bathinda districts of Punjab. Their findings suggest that these areas possess significantly higher levels of $\mathrm{F}$ in its water sources.

Table 1: Fluoride concentration in drinking water, urine and milk of livestock in fluoride and non-fluoride endemic area

\begin{tabular}{lllll}
\hline & & $\begin{array}{l}\text { Water } \\
(\mathbf{N}=\mathbf{7})\end{array}$ & $\begin{array}{l}\text { Urine } \\
(\mathbf{N}=\mathbf{8})\end{array}$ & $\begin{array}{l}\text { Milk } \\
(\mathbf{N}=\mathbf{6})\end{array}$ \\
\hline $\begin{array}{l}\text { Fluoride } \\
\text { endemic area }\end{array}$ & Mean \pm SD & $3.71 \pm 1.01$ & $16.1 \pm 2.13$ & $0.54 \pm 0.11$ \\
& Min & 2 & 10 & 0.4 \\
& Max & 8 & 30 & 0.8 \\
\cline { 2 - 5 } & & Water & Urine & Milk \\
& & $(\mathbf{N}=\mathbf{6})$ & $\mathbf{N = 5 )}$ & $(\mathbf{N = 9 )}$ \\
\hline $\begin{array}{l}\text { Non- fluoride } \\
\text { endemic area }\end{array}$ & Mean \pm SD & $0.25 \pm 0.01$ & $3.4 \pm 1.05$ & $0.06 \pm 0.02$ \\
& Min & 0.2 & 3 & 0.04 \\
& Max & 0.3 & 4 & 0.08 \\
\hline
\end{tabular}

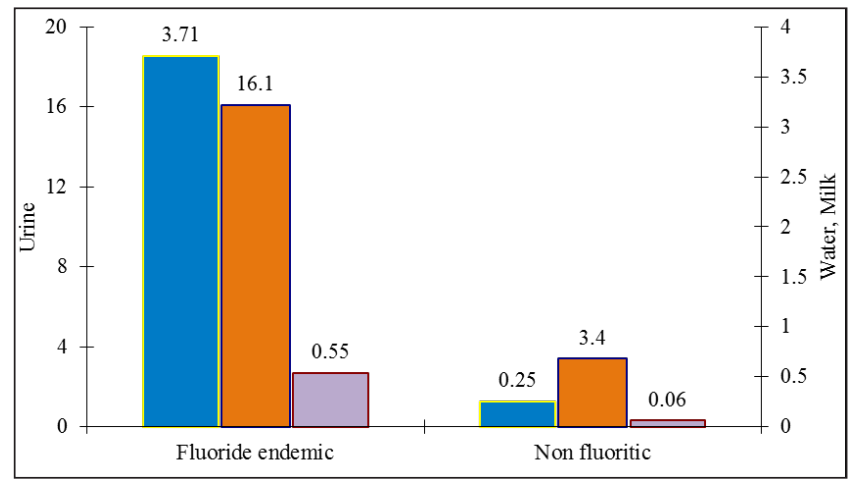

Fig. 1: Relationship between F concentration in drinking water, urine and milk of livestock in fluoride and non-fluoride endemic areas

The higher F concentration in the water can be of geogenic origin. Giri et al. (2013) revealed that the weathering and leaching process by percolating water in soil belts plays an important role in the occurrence of $\mathrm{F}$ in groundwater. Chatterjee et al. (2008) and Keesari et al. (2007) suggested that high $\mathrm{F}$ in ground water may be due to leaching from fluoride-rich rocks present in the subsurface as well as due to anthropogenic activities. Several other workers (Beg et al., 2011, Sharma et al., 2004) reported that high F levels in groundwater were largely governed by presence of $\mathrm{Ca}$, 
$\mathrm{Mg}, \mathrm{Na}, \mathrm{SiO}_{2}, \mathrm{PO}_{4}, \mathrm{pH}$ and alkalinity of the earth's crust. In the present study, it can be concluded that hydrofluorosis was a major problem in the ground water and is responsible for dental and skeletal fluorosis in the dairy animals.

\section{Fluoride concentration in milk and urine of livestock} in Fluoride endemic and non- fluoride endemic area

In the present study, the mean F concentration in milk and urine of fluoritic buffaloes in Mansa district was found to be $0.54 \pm 0.11$, ranging from 0.4 to $0.8 \mathrm{mg} / 1$ and $16.1 \pm 2.13$, ranging from 10 to $30 \mathrm{mg} / 1$ respectively, consuming water with $\mathrm{F}$ levels ranging from 2-8ppm. In the milk and urine samples collected from the dairy animals from the non fluorotic area, the values were much less and were in the range of 0.04 to $0.08 \mathrm{mg} / \mathrm{l}$ and 3 to $4 \mathrm{mg} / 1$ respectively as given in Table 1, Fig. 1. Somewhat similar observations were made by Gupta et al. (2015) and reported that in three zones of Mathura the mean fluoride concentration of drinking water, cow's milk and buffalo's milk were $0.89 \pm 0.39,0.09 \pm 0.07,0.09 \pm 0.08$ respectively. Similarly, Dahariya et al. (2015) reported the exposure of high F levels in contaminated groundwater by domestic animals of Dongargarh city, Chhattisgarh results in excess $\mathrm{F}$ excretion through urine of animals.

\section{CONCLUSION}

Fluorosis is the condition which is caused by intake of small but toxic amounts of fluoride in feed or drinking water over a long duration of time which is characterized by mottling of teeth and osteosclerosis of skeleton which is a serious health hazard. With increase in concentration of fluoride in drinking water, there was increase concentration of fluoride in milk and urine which can also be used as a diagnostic indicator for detection of animals suffering from fluorosis.

\section{REFERENCES}

Beg, M.K., Srivastav, S.K., Carranza, E.J.M. and de, S.J.B. 2011. High fluoride incidence in groundwater and its potential health effects in parts of Raigarh district, Chhattisgarh, India. Curr. Sci.,, 100(5): 750-754.

Chatterjee, A., Roy, R.K. Ghosh, U.C., Pramanik, T., Kabi, S.P. and Biswas, K. 2008. Fluoride in water in parts of Ranniganj Coalfield, West Bengal. Curr. Sci., 94: 309-311.
Dahariya, N.S., Rajhans, K.P., Yadav, A., Ramteke, S., Sahu, B.L. and Patel, K.S. 2015. Fluoride contamination of groundwater and health hazard in central India. Journal of Water Resource and Protection, 7: 1416-1428.

Gupta, P., Gupta, N., Meena, K., Moon, N.J. Kumar, P. and Kaur, R. 2015. Concentration of fluoride in cow's and buffalo's milk in relation to varying levels of fluoride concentration in drinking water of Mathura city in India - A pilot study. $J$. Clin. Diagn. Res., 9(5): 05-07.

Giri, D.K., Ghosh, R.C., Dey, S., Mondal, M., Kashyap, D.K. and Dewanagan, G. 2013. Incidence of hydrofluorosis and its adverse effects on animal health in Drug district, Chhattisgarh. Curr. Sci., 105(11): 1477-1479.

Keesari, T., Shivanna, K. Jalihal, A.A. 2007. Isotope hyrrochemical approach to understand Fluoride release into groundwaters of Ilkal Area, Bagalkot District, Karnataka, India. J. Hydrol., 15: 589-598.

Modasiya, V., Bohra, D.L., Daiya, G.S. and Bahura, C.K. 2014. Observations of fluorosis in domestic animals of the Indian Thar Desert, Rajasthan, India. Int. J. Adv. Res., 2(4): 11371143.

Pradhan, B.C., Baral, M., Prasad, S., Pradhan, D. 2016. Assessment of fluoride in milk samples of animals of around Nalco Angul Odisha, India. Int. J. Innov. Pharm. Sci. Res., 4(1): 29-40.

Randhawa, S.S. and Singh, S.T. 2010. Mineral toxicities in dairy animals. Paper presented at National Symposium of ISVM on Recent Development in Diagnostic and Therapeutic Approaches for Economic Important Diseases of Livestock and Companion animals, held at Bombay Veterinary College, Mumbai from Feb. 17 to 19, India.

Radostits, O.M., Henchcliff, K.W., Gay, C.C. and Constable, P.D. 2007. Veterinary Medicine: A Textbook of the Diseases of Cattle, Horses, Sheep, Pigs and Goats. $10^{\text {th }}$ Edn. W B Sounders Harcourt Publishers Ltd, London, pp. 1815-19.

Singh, S.T. 2012. 'Surveillance, clinico-biochemical and therapeutic studies on mineral imbalances in dairy animals of south-western region of Punjab.' Ph.D. dissertation. Guru Angad Dev Veterinary and Animal Sciences University, Ludhiana, India.

Sharma, C., Mahajan, A., Garg, U.K. 2014. Fluoride and nitrate in groundwater of south-western Punjab, India - occurrence, distribution and statistical analysis. Desalination and Water Treatment, 57(9): 1-12.

Sharma, R. and Pervez, S. 2004. Study of dental fluorosis in subjects related to a phosphatic fertilizer plant environment in Chhattisgarh state. J. Sci. Ind. Res., 63: 985-988. 
